\title{
CSR in Sustainable Development: Comparative Analysis
}

\author{
DOI: 10.12776/QIP.V21I3.943
}

\author{
Marina Khayrullina
}

Received: 21 July 2017

Accepted: 27 August 2017

Published: 30 November 2017

\begin{abstract}
Purpose: To identify global and national trends in the development of CR reporting, the main difficulties in the CSR extension in Russia and suggest ways to improve a policy framework in the sphere of GRI based on the analysis of non-financial reporting by countries and regions of the world.

Methodology/Approach: Researching and writing the article one uses a combination of systemic and structural-functional approaches approach. The argumentation of the main provisions and conclusions is based on the application of comparisons, statistical, graph and tabular analysis methods. The information and empirical basis of the study are the legislative and normative acts of the Russian Federation, industries and regions development concepts and programs, data of state statistics bodies, materials of periodicals, conferences, roundtables, seminars, as well as the results of intermediate research carried out by the author personally.
\end{abstract}

Findings: The essential feature of the Russian CSR model is the decisive role of the state in its development. Non-financial reporting in Russia develops with slower rates than in developed countries. The methodological weakness of the reports is reflected in relatively low share of integrated reports, their incomplete compliance with international standards, methodological differences in calculations of the similar indicators. Development of CSR in Russia is connected with further study and adaptation of international best practices including a six-stage model of CSR policy formation.

Research Limitation/implication: As a result of the study, the main difficulties in the CSR extension in Russia were identified which are typical for all Russian regions and industries. Regional authorities can conduct an analysis of local difficulties and problems on this basis. The six-stage model of CSR policy formation can be used at any level of govenance with minor modifications. As a complex, these measures will solve the identified problems both at the level of regions and Russia as a whole. 
Originality/Value of paper: The comparative analysis results of non-financial reporting development are author's and can be used as a basis for further analytical calculations. The findings, difficulties and directions for improving sustainable development policies in Russia in a complex develop theoretical knowledge on sustainable development, form the basis for the development and implementation of new practices within the policy framework.

Category: Research paper

Keywords: corporate social responsibility; sustainable development; nonfinancial reporting

\section{INTRODUCTION}

In a general sense, Corporate Social Responsibility (CSR) means a voluntary contribution of corporations to society development in the social, economic and ecological spheres, and this contribution is directly connected with the core activities of the company and is beyond a certain legislative minimum. This tool with the aim to achieve sustainable development goals is on a company's level.

The ideas grounding the concept of sustainable development (Brundtland Commission, 1987) and later concretized in a series of documents of the Conference on Environment and Development in Rio de Janeiro in 1992, are not principally novel for Russia. In the recent ten years, Russia has created institutional environment, regulatory and legal framework, which are directed to regulate many issues of sustainable development in individual regions and in the country in general (Hajduova, et al., 2016). The understanding of the role of companies in ensuring sustainable development of the economy and society has been changed. Nowadays, it is connected not only with the maximization of profit and company's value growth, dividend and salary payments to employees, but also with the contribution to the solving of social, economic and ecological problems. Corporate social responsibility and corporate sustainability are considered as a new step of the economic relations evolution, transition to a new paradigm of sustainable development on the global and corporate level.

The following documents contribute to that: The UN Sustainable Development Goals of the 2030 Agenda for Sustainable Development (Sustainable Development Goals, 2015), decisions of the Paris Climate Summit, Action Agenda for Financing for Development in Addis Ababa, Task Force on Climaterelated Financial Disclosures by the Financial Stability Board, Mandatory ESGreporting Requirements (LSEG, 2017), which strengthen the interest of various stakeholders towards the company's impact on the economy, society and environment.

This tool is relatively new for Russia. The problems of its practical implementation are due to the deficiency or imperfection of methodological and legislative basis, business mentality, corporate culture, weak policy in the sphere 
of sustainable development in general. In this connection, the international experience is of great interest and its adaptation could promote CSR development in Russia.

\section{GENERAL THEORETICAL PRINCIPLES}

The modern CSR structure includes the following aspects:

- the triple bottom line (economic responsibility - profit, ecological responsibility - planet, social responsibility - people) (Slaper and Hall, 2011);

- responsibility to internal and external stakeholders;

- liabilities to stakeholders, these liabilities both are enshrined in the law and undertaken on a voluntary basis.

As a rule, the responsibility is implemented through the following types of activities: elaboration of a corporate social policy of a company; corporate management and corporate ethics; labor protection; elaboration of a policy in the sphere of environmental protection; environment-related activities; human resources management (programs for personnel development and raising of their living standards; social investments); interrelations with local communities, authorities, mass media; corporate charity, sponsorship, volunteering; fair competition; anticorruption efforts; reporting, transparency and public information on the company's activities; public service advertising and others.

CSR has a multilevel character, i.e. basic level (performance of legislative and regulated liabilities); high level (includes types of liabilities mostly connected with social investments, labor and environmental protection); advanced level (covers all the types of activities, including charity).

The Russian model of CSR in terms of driving forces, practical application and role of non-governmental organizations is something in the middle between the British model (initiated by business) and the continental model (state initiative and clear legislative framework). The Russian CSR model is oriented to a narrow group of stakeholders, including the state, owners and employees of companies. Local communities, suppliers and others are not included in this process to the full extent for the time being. The essential feature of the Russian CSR model is the decisive role of the state in its development.

Non-financial reporting is of a crucial significance for the CSR development, for studies and improvements of this system all over the world. Let us discuss it in more details. 


\section{NON-FINANCIAL REPORTING AND ITS DEVELOPMENT IN RUSSIA (COMPARATIVE ANALYSIS)}

\subsection{General Characterization of the Situation}

The growth of demand for reliable and transparent information stimulates evergrowing use of tools of independent assessment of company's operations on the basis of the analysis of their public and non-financial reporting (Dragunova, 2006).

Non-financial reporting means documents officially published by companies, these documents present to stakeholders data on results of the companies' activities in the sphere of CSR and sustainable development. As a rule, such documents contain data on the company's strategy, observance of ethical principles in business operations, quality of the corporate management, contribution to environmental protection, observance of human rights, human resources management, quality of products and services, support to local communities, impact of the company on the society through all the key directions of its activities including of intangible assets (Khomenko, 2014).

The development of non-financial reporting in Russia is in the early stages, and it is characterized by the following factors.

1. Regulatory processes. Requirements of the ESG-reporting. Here the following documents should be mentioned: Corporate Governance Code of the Bank of Russia and Concept of Development of Public Non-Financial Reporting.

The Code contains direct recommendations to disclose the following information in the sphere of social and environmental responsibilities:

- policy in social and environmental spheres;

- reports on sustainable development prepared in compliance with the international standards (GRI);

- results of the audit of quality management systems, certification of the quality management system in compliance with the requirements of the international standard.

The Concept of Development of Public Non-financial Reporting (elaborated by the Ministry of Economic Development of the Russian Federation) determines the principles and forms of the public non-financial reporting, mechanisms of its preparation, internal control and external evaluation. It refers mostly to largescale enterprises (Amanzholova, 2014; Amanzholova, Fribus and Khomenko, 2016).

It is supposed that the requirements of the mandatory non-financial reporting would be consistently extended to the following organizations taking into account their compliance with the criteria of the range of activities: state corporations; large-scale state companies; partially government-owned companies and state unitary enterprises; companies included by the government 
in the special lists of strategic and systemically-important companies of the Russian Federation; large-scale private companies, whose securities are admitted to on-exchange trading, as well as companies, which are included in Russian ratings as the largest organizations in terms of the total volume of revenue.

2. Independent assessment of the company's operation. Nowadays, there are designed various systematic national and industry ratings, as follows:

- indices and ratings in the sphere of sustainable development and corporate responsibility, for example, "Responsibility and Transparency" index and "Vector of Sustainable Development" index of the Russian Union of Industrialists and Entrepreneurs (RSPP);

- National index of corporate governance (National Association of Corporate Directors, Moscow Exchange, RSPP);

- Rating of fundamental (ecological-energy) efficiency (Interfax-ERA);

- Rating of ecological responsibility of oil and gas companies (WWF, National Rating Agency and CREON company);

- Rating of ecological responsibility of mining companies (WWF and Ministry of Natural Resources of the Russian Federation);

- Rating of forest management (WWF);

- Sustainable Development Ranking for Selected Russian Cities (SGM);

- Ecological rating of regions and cities of Russia (Lomonosov Moscow State University).

\section{The RSPP National Register of Corporate Non-Financial Reports.}

This is a database of voluntary non-financial reports of organizations operating on the territory of the Russian Federation.

\subsection{Dynamics of Number of Non-Financial Reports}

Non-financial reporting in Russia develops more slowly than in developed countries, which can be proved by the dynamics of non-financial reports and organizations reporting (Fig. 1).

The most complete information on the number of Russian companies which publish non-financial reports and on the approaches towards reporting is contained in the National Register of Corporate Non-Financial Reports and in the Library of corporate non-financial reports formed by RSPP (Feoktistova, et al., 2017).

Since 2011, a certain slow-up of the process is observed, which corresponds to the global trend, i.e. when the most large-scale companies have started to publish reports in a sustained way, the dynamics of the year-on-year increase of reports decreases. 


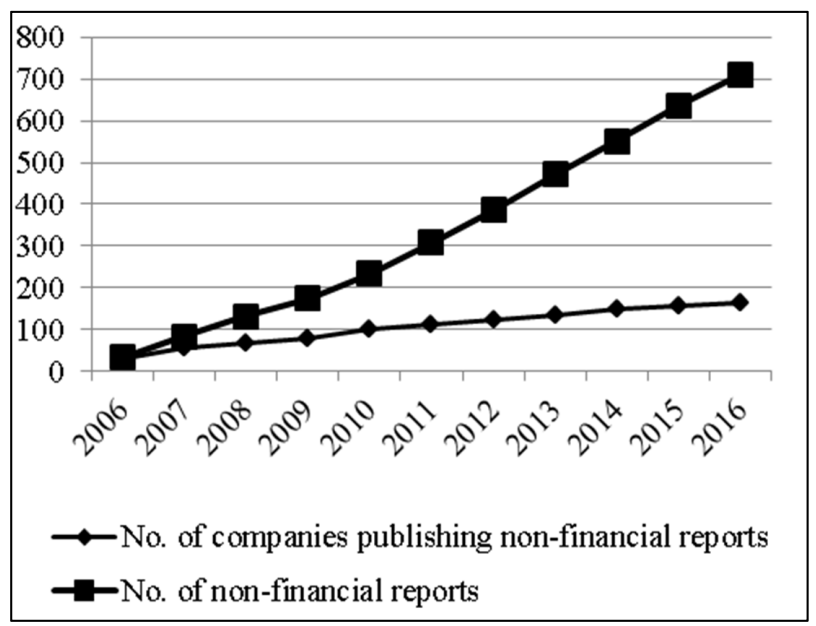

Figure 1-Dynamics of Non-Financial Reports and Companies Reporting in Russia in 2006-2016 (Cumulative)

According to the open information of The World's Largest CR Report Directory «Corporate Register», the total number of organizations presenting non-financial reporting in the world was 13,936 (by the beginning of 2016), the total number of reports in the database is 83,914 . Statistics per country and macro-regions looks in the following way (Tab. 1) (Corporate Register, 2016).

Table 1 - Statistics of Non-Financial Reporting per Country and Region of the World, 2016

\begin{tabular}{|c|c|c|c|c|}
\hline \multirow{2}{*}{$\begin{array}{c}\text { Compared macro-regions / } \\
\text { countries }\end{array}$} & \multirow{2}{*}{$\begin{array}{c}\text { No. of } \\
\text { organizations }\end{array}$} & \multirow{2}{*}{ No. of reports } & \multicolumn{2}{|c|}{$\begin{array}{l}\text { Share in the No. } \\
\text { of organizations }\end{array}$} \\
\hline & & & $\begin{array}{c}\text { of the } \\
\text { country, \% }\end{array}$ & $\begin{array}{l}\text { of the macro- } \\
\text { region, } \%\end{array}$ \\
\hline Western Europe & 4,454 & 25,633 & 100 & 47.3 \\
\hline \multicolumn{5}{|c|}{ with the largest share in the number of organizations } \\
\hline Great Britain & 1,352 & 8,628 & 30.4 & 14.4 \\
\hline Germany & 1,050 & 5,671 & 23.6 & 11.1 \\
\hline France & 631 & 3,679 & 14.2 & 6.7 \\
\hline Southern Europe & 1,634 & 9,634 & 100 & 17.3 \\
\hline \multicolumn{5}{|c|}{ with the largest share in the number of organizations } \\
\hline Spain & 779 & 4,199 & 47.7 & 8.3 \\
\hline Italy & 572 & 3,589 & 35.0 & 6.1 \\
\hline USA & 1,632 & 9,324 & - & 17.3 \\
\hline
\end{tabular}




\begin{tabular}{|l|c|c|c|c|}
\hline \multirow{2}{*}{$\begin{array}{c}\text { Compared macro-regions / } \\
\text { countries }\end{array}$} & $\begin{array}{c}\text { No. of } \\
\text { organizations }\end{array}$ & No. of reports & \multicolumn{2}{|c|}{$\begin{array}{c}\text { Share in the No. } \\
\text { of organizations }\end{array}$} \\
\cline { 3 - 5 } & & $\begin{array}{c}\text { of the } \\
\text { country, \% }\end{array}$ & $\begin{array}{c}\text { of the macro- } \\
\text { region, \% }\end{array}$ \\
\hline Northern Europe & 907 & 6,304 & 100 & 9.6 \\
\hline with the largest share in the number of organizations & 2,633 & 43.0 & 4.1 \\
\hline Sweden & 390 & 1,267 & 19.2 & 1.8 \\
\hline Denmark & 174 & 1,272 & 18.1 & 1.7 \\
\hline Finland & 164 & 956 & 16.4 & 1.6 \\
\hline Norway & 149 & 3,385 & - & 5.2 \\
\hline Canada & 492 & 1,613 & 100 & 3.2 \\
\hline Eastern Europe & 300 & 466 & 27.3 & 0.9 \\
\hline with the largest share in the number of organizations & 82 & 369 & 26.0 & 0.8 \\
\hline Russia & 78 & 314 & 21.0 & 0.7 \\
\hline Poland & 63 & 55,893 & - & 100 \\
\hline Hungary & 9,419 & & & \\
\hline Total & \multicolumn{5}{|l|}{}
\end{tabular}

Large-scale companies in Italy, Spain and the UK are the leaders in the world in terms of the quality of CR reports.

Russia belongs to the group of Eastern European countries, where the processes of the CSR development are slow in comparison with that in other macro-regions (3.2\% of the total comparative base). In its macro-region, Russia holds a share of $27.3 \%$ in terms of socially responsible organizations and $0.9 \%$ in terms of compared countries.

The comparison within BRICS countries also shows low positions of Russia in terms of the dynamics of non-financial reporting:

- Brazil - 520 companies and 2883 reports;

- RSA - 330 companies and 2201 reports;

- India - 156 companies and 856 reports;

- China - 111 companies and 504 reports, respectively (Corporate Register, 2016).

\subsection{Dynamics of Number of Non-Financial Reports}

The composition of companies which submit their reports in Russia corresponds to the international trends. As before, mostly large-scale companies operating on 
the international level and on the financial markets prepare non-financial reporting (Tab. 2).

Table 2 - The Top Five Industries and Companies of Russia Submitting Non-Financial Reports, 2016

\begin{tabular}{|c|c|c|}
\hline Industry & Key companies & Number of reports \\
\hline Oil and gas & $\begin{array}{l}\text { PJSC “ Gazprom"; PJSC “Gazprom Neft" } \\
\text { (JSC "SibNeft"); PJSC "TatNeft”; JSC } \\
\text { "NOVATEK"; PJSC "RosNeft", }\end{array}$ & 12 \\
\hline Metallurgy and mining & $\begin{array}{l}\text { JSC "Magnitogorsk Iron and Steel Works"; } \\
\text { RUSAL (Russian Aluminum); PJSC "Norilsk } \\
\text { Nickel" }\end{array}$ & 11 \\
\hline $\begin{array}{l}\text { Chemistry and } \\
\text { petrochemical industry }\end{array}$ & $\begin{array}{l}\text { JSC EuroChem; PJSC } \\
\text { "Nizhnekamskneftekhim"; JSC "Siberian } \\
\text { Chemical Combine (SKhK)" }\end{array}$ & 10 \\
\hline Nuclear industry & $\begin{array}{l}\text { The State Atomic Energy Corporation } \\
\text { "ROSATOM"; JSC "TVEL Fuel Company"; } \\
\text { JSC "RosEnergoAtom" }\end{array}$ & 9 \\
\hline $\begin{array}{l}\text { Electrical energy } \\
\text { industry }\end{array}$ & $\begin{array}{l}\text { PJSC "MOESK" (Moscow United Electric } \\
\text { Grid Company); PJSC "Federal Grid } \\
\text { Company - Unified Energy System of } \\
\text { Russia"; PJSC "RusHydro" }\end{array}$ & 9 \\
\hline
\end{tabular}

But there are observed some distinctions between industries.

The KPMG experts assessed the quality of reporting among the world's largest 250 global companies. These were identified as the top 250 companies listed in the Fortune Global 500 ranking for 2012. In this survey they are referred to as "the G250" companies (KPMG, 2013). They are distributed per industries in the following way:

- Finance, insurance \& securities $(25 \%)$;

- Oil \& gas (13\%);

- Trade \& retail (11\%);

- Automotive (7\%);

- Electronics \& computers (7\%).

In Russia, non-financial reporting is developed mostly in the fuel and energy complex. 


\subsection{Dynamics of Number of Non-Financial Reports}

There are the following types of non-financial reports in Russia (Fig. 2):

- sustainable development reports (in compliance with the methods of Global Reporting Initiative, GRI);

- integrated reports (in compliance with the international standard IR);

- social reports (The Social Charter and Basic Performance Indicators by RSPP);

- environmental reports (statistical data forms of environmental reporting);

- branch reports.

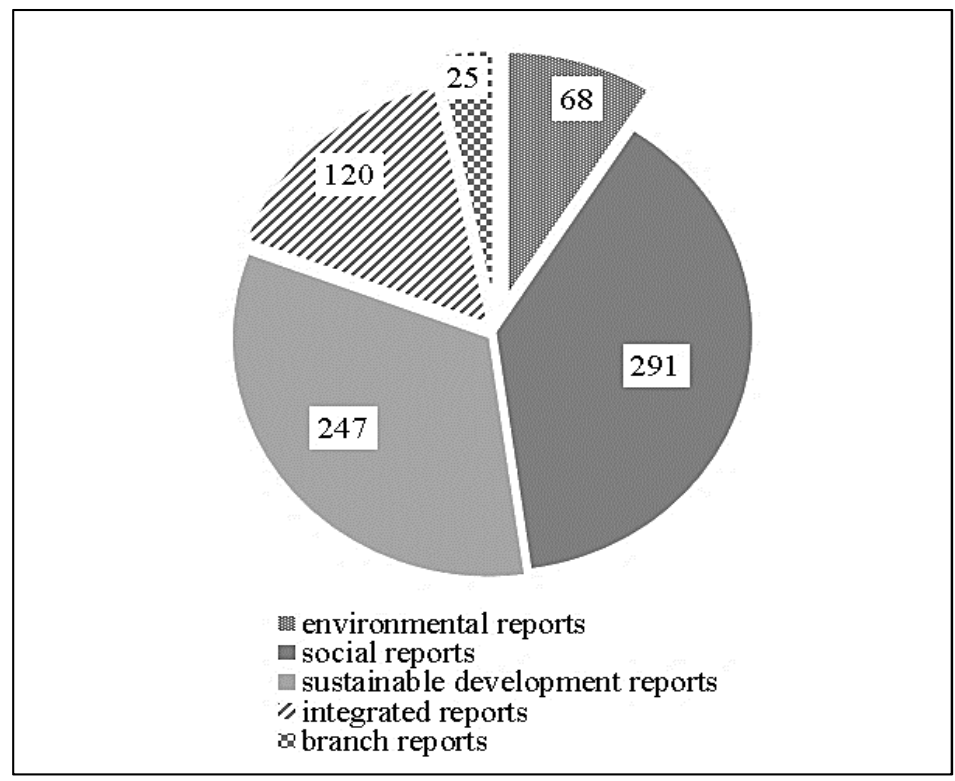

Figure 2 - Types of Non-Financial Reports in Russia, 2016

At the same time, the share of integrated reports in the total number of reports was in average about $74 \%$ in 2006-2016 (including integrated reports, $14 \%$, social reports, $20 \%$, environmental reports, $6 \%$ ).

The integrated reports do not yet in the form and structure sufficiently differ from sustainable development reports or traditional annual reports, and they include as a rule the following issues:

- market analysis;

- financial and production results;

- corporate governance reports;

- industry-specific themes (in accordance with the materiality matrix);

- company's overview in the sphere of personnel management;

- company's overview in the sphere of environmental protection and social investments; 
- financial performance.

The weak point in the methodology of reports preparation is a relatively small share of integrated reports, which, in their turn, are not always in compliance with international standards.

Nevertheless, Russia is in line with the worldwide trends of the CR reporting development:

- growth of data number;

- dynamic growth of number of reports in countries with developing economy;

- narrowing gap between branches of economy; CR reporting becomes a standard of practice regardless of a branch;

- growth of platforms and guidelines for reporting;

- growth of necessity in audit / assessment / assurance of public reporting.

\section{MAIN PROBLEMS IN CSR DEVELOPMENT IN RUSSIA AND WAYS OF THEIR SOLVING}

As a result of the study, the following main difficulties in the CSR extension in Russia can be identified:

1) Sluggishness of processes of integration of the concept, principles and indicators of sustainable development with strategies and systems of enterprises management.

2) Scarcity of financial resources for small- and medium-size companies for the implementation of a complex policy of social responsibility; in this connection, mostly large national companies, affiliated organizations and subsidiary enterprises of international companies located on the territory of the Russian Federation are involved in CSR processes.

3) Mentality of the Russian business, which used to work in the framework of short-term goals, thus minimizing risks, and which is not ready for long-term investments; relatively often changing political and economic situation in the country, that does not allow to change this mentality within a certain historic period; and, as a result, the established tradition to finance large social projects by the government funds only.

4) The spatial organization of the country with extended territories, low-level population density in some territories, underdeveloped infrastructure (including transport), concentration of capital in large megalopolises, does not stimulate companies to develop CSR.

5) Social passivity of the majority of the population of Russia, weak trade union movement. Strong parties and movements, associations, nongovernmental organizations, which now act in the civil society structure, are created by the initiative of government authorities and local selfgovernment. 
6) Veiled compulsory nature of CSR, which is mostly pronounced in regions and on the local level, when enterprises are forced to implement social projects in order to gain preferences from local authorities; thus violating the principle of voluntariness, reducing confidence in the power, and demotivating companies to implement CSR. As a result, companies submit information referring to their support and development of the social sphere not to beneficiaries directly, but primarily to government authorities and local self-government.

7) The deficiency of comparable and balanced information, disclosed by different companies in terms of the same directions of non-financial reporting; different calculation methods, which cause different interpretations of the information presented in CSR reports. At the same time, it should be mentioned that Russian methods of CSR assessment are in compliance with the international standards (GRI, ISO 26000, AA1000SES, AA1000AS, SA8000). Thus, in particular, the RSPP basic indicators are in compliance with the GRI standard to the fullest extent possible. But they are limited to the scope of the standard data of enterprises, and they do not contain a set of indicators reflecting management and corporate government.

In order to solve these problems, first of all, it is necessary to elaborate and constantly improve a policy framework in the sphere of GRI (Srinivas, 2015; Albareda, et al., 2008). To this effect, it is proposed to use a six-stage model (The United Nations Global Compact, 2010):

- Stage 1. Understanding CR-relevant context.

- Stage 2. Defining corporate responsibility.

- Stage 3. Situating CR within a government structure.

- Stage 4. Defining the CR public policy rationale.

- Stage 5. Identifying types of policy intervention for CR.

- Stage 6. Monitoring and impact assessment.

As an addition to the mentioned model, the following factors are important:

- Strengthening of ecological aspects in the non-financial reporting, because the problem of climate changes would predominate in the world practice of non-financial reporting.

- Introduction of sustainable development principles into supply chains (business-models of companies).

- Elaboration of a uniform generally accepted standard of non-financial reporting (like a standard of financial reporting) taking into account peculiarities of the Russian financial accounting; management accounting, and statistical accounting, statutorily prescribed obligations.

As a complex, these measures would make it possible to start the solving of the problems mentioned above. But their complete solution is possible only in case of the participation of all stakeholders and within timeframes allowing for global 
changes and changes in the mentality. To our regret, they are not limited by the near-term outlook.

\section{CONCLUSION}

The studies of international experience and results of quantitative and qualitative cross-country comparisons made it possible to identify the main trends and difficulties in the CSR development in Russia. The essential feature of the Russian CSR model is the decisive role of the state in its development. Nonfinancial reporting in Russia develops with slower rates than in developed countries, and it is prepared mostly by large-scale companies of the fuel and energy complex, as well as by companies operating on the international level and on the financial markets. The methodological weakness of the reports is reflected in relatively low share of integrated reports, their incomplete compliance with international standards, methodological differences in calculations of the similar indicators.

The further development of CSR in Russia involves overcoming of institutional, mental, financial difficulties, improvement of the policy framework of the state, further study and adaptation of international best practices.

\section{ACKNOWLEDGMENTS}

The results of research were received within performance of the state task of the Ministry of Education and Science of the Russian Federation, the project 26.2024.2017/4.6.

\section{REFERENCES}

Albareda, L., Lozano, J.M., Tencati, A., Midttun A. and Perrini, F., 2008. The changing role of governments in corporate social responsibility: drivers and responses. Business Ethics: A European Review, [e-journal] 17(4), pp.347-363. http://dx.doi.org/10.1111/j.1467-8608.2008.00539.x.

Amanzholova, B., 2014. Accounting and public expectations: interrelations and transformation of accounting control function. In: SGEM (Social Sciences \& Arts), $1^{\text {st }}$ International multidisciplinary scientific conference on social sciences and arts. Bulgaria, Albena, 1-4 September 2014. Sofia: TEF92 Technology.

Amanzholova, B., Fribus, N. and Khomenko, E., 2016. Disclosure of information on ecological activity as a factor of sustainable development of manufacturing enterprises. In: APEIE (Actual Problems of Electronic Instrument Engineering), 12th International Scientific-Technical Conference on Actual Problems of Electronic Instrument Engineering. Russia, Novosibirsk, 2-4 October 2014. USA: IEEE. 
Corporate Register, 2017. The world's largest CR report directory. [online] Available at: <http://www.corporateregister.com/map/> [Accessed 05 July 2016].

Dragunova, E., 2006. National features of Russian entrepreneurs. International Journal of Entrepreneurship and Small Business, 3(5), pp.607-620.

Feoktistova, E.N., Alenicheva, L.V., Dolgikh, E.I., Kopylova, G.A., Ozeryanskaya, M.N. and Khonyakova, N.V., 2017. Analiticheskii obzor korporativnykh nefinansovykh otchetov: 2015-2016. Moscow: RSPP.

Hajduova, Z., Bosák, M., Andrejovský, P., Lacko, R., Khayrullina, M., Shcherbakova, N. and Gorevaya, E., 2016. Sustainable Development in Conditions of Slovakia and Russia. Brussels: EuroScientia.

Khomenko, E., 2014. University reporting of intangible assets: developing the framework of the information disclosure. In: SGEM (Social Sciences \& Arts), $1^{\text {st }}$ International multidisciplinary scientific conference on social sciences and arts. Bulgaria, Albena, 1-4 September 2014. Sofia: TEF92 Technology.

KPMG, 2013. The KPMG Survey of Corporate Responsibility Reporting 2013. [online] s.l., KPMG International. Available at: <kpmg.com/sustainability $>$ [Accessed 04 August 2016].

London Stock Exchange Group (LSEG), 2017. Revealing the full picture: Your guide to ESG. [online] London: Stock Exchange Group. Available at: $<$ http://www.lseg.com/sites/default/files/content/images/Green_Finance/ESG_Gu idance_Report_LSEG.pdf> [Accessed 25 August 2016].

Brundtland Commission, 1987. Report of the World Commission on Environment and Development: Our Common Future. [pdf] s.l., UN Documents, Gathering a Body of Global Agreements. Available at: <http://www.un-documents.net/ourcommon-future> [Accessed 14 June 2016].

Slaper, T.F. and Hall, T.J., 2011. The Triple Bottom Line: What Is It and How Does It Work?. Indiana Business Review, 86(1): pp.4-8.

Srinivas, H., 2015. The Role of Local Governments in Fostering Business Partnerships for Environmental Sustainability. Policy Analysis Series E-076, [online]. Available at: <https://www.gdrc.org/sustbiz/bizpartnerships.html> [Accessed 05 April 2016].

Sustainable Development Goals, 2015. United Nations Department of Economic and Social Affairs. [online] Available at: $<$ https://sustainabledevelopment.un.org/sdgs $>$ [Accessed 25 August 2016].

The United Nations Global Compact, 2010. The Role of Governments in Promoting Corporate Responsibility and Private Sector Engagement in Development. [online] New York: The Bertelsmann Stiftung. Available at: $<$ http://www.vub.ac.be/klimostoolkit/sites/default/files/documents/role_of_gover nments_in_csr.pdf $>$ [Accessed 05 April 2016]. 


\section{ABOUT THE AUTHOR}

Prof. Marina Khayrullina, D.Sc., Dean of the Faculty of Business, Novosibirsk State Technical University, K. Marx, 20, Novosibirsk, Russian Federation, e-mail: khayrullina@corp.nstu.ru. Authors' ORCID 0000-0003-2028-0161.

(C) 2017 by the authors. Submitted for possible open access publication under the terms and conditions of the Creative Commons Attribution (CC-BY) license (http://creativecommons.org/licenses/by/4.0/). 